\title{
Efficiency of composted vinasse in the production of basil (Ocimum basilicum L.) under greenhouse conditions
}

\author{
Vinas kompostunun örtüaltında fesleğen (Ocimum basilicum L.) üretiminde etkinliği

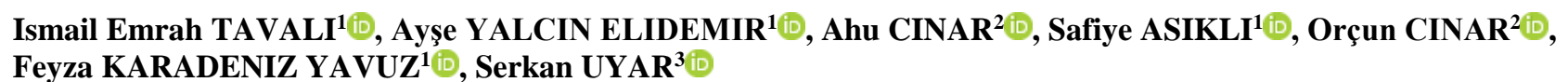

${ }^{1}$ Department of Medicinal and Aromatic Plants, Gazipaşa M.R.B. Vocational School, Alanya Alaaddin Keykubat University, Antalya, Turkey ${ }^{2}$ Western Mediterranean Agricultural Research Institute (BATEM), Republic of Turkey Ministry of Agriculture and Forestry, Antalya, Turkey ${ }^{3}$ Department of Grassland Planting and Management, Serik Gülsün-Süleyman Süral Vocational School, Akdeniz University, Antalya, Turkey

Corresponding author (Sorumlu yazar): S. Asikli, e-mail (e-posta): safiye.asikli@alanya.edu.tr

Author(s) e-mail (Yazar(lar) e-posta): emrah.tavali@alanya.edu.tr, ayse.yalcin@alanya.edu.tr, ahu.cinar@tarimorman.gov.tr, orcun.cinar@tarimorman.gov.tr, feyza.yavuz@alanya.edu.tr, serkanuyar@akdeniz.edu.tr

\section{ARTICLE INFO}

Received 02 November 2020

Received in revised form 10 May 2021

Accepted 10 May 2021

\section{Keywords:}

Ocimum basilicum L.

Linalool

Organic fertilizing material

Essential oil

\section{ABSTRACT}

The aim of this study was to determine the effectiveness of vinasse, which is known to be a good source of organic matter and potassium in the production of an aromatic plant. In this context, the vinasse, which is a food industry waste, was composted and applied to the soil alone and mixed with chemical fertilizers in different doses [Only chemical fertilizationcontrol (C), vinasse compost $0.5 \mathrm{t} \mathrm{ha}^{-1}$ (VC-0.5), vinasse compost $0.5 \mathrm{t} \mathrm{ha}^{-1}+$ chemical fertilization $0.5 \mathrm{t} \mathrm{ha}^{-1}(\mathrm{VC}-0.5+\mathrm{CF})$, vinasse compost $1 \mathrm{t} \mathrm{ha}^{-1}(\mathrm{VC}-1)$, vinasse compost $1 \mathrm{tha}^{-1}$ + chemical fertilization $1 \mathrm{t} \mathrm{ha}^{-1}$ (VC-1+CF)] and thus, basil (Ocimum basilicum L.) was produced under greenhouse conditions. Plants were harvested three times in a row when they reached the flowering period. Morphological (number of branches, flower spike height, plant height, fresh weight), agronomic (green herb/drug yield, dry weight) and technological (essential oil ratio, essential oil composition, color value) parameters were examined in the harvested samples. According to the results obtained; while the highest fresh weight, green herb yield and dry weight were obtained by $\mathrm{VC}+\mathrm{CF}$, the highest essential oil ratio in the plant was observed in VC. The striking point here is that these results were obtained with $0.5 \mathrm{t} \mathrm{ha}^{-1}$ application rate of the compost. The findings obtained from this study reveal that the compost can be used in basil cultivation together with chemical fertilization.

\section{MAKALE BİLGISİ}

Alınış tarihi 02 Kasım 2020

Düzeltilme tarihi 10 Mayıs 2021

Kabul tarihi 10 Mayıs 2021

\section{Anahtar Kelimeler:}

Ocimum basilicum L.

Linalool

Organik gübreleme materyali

Uçucu yă

\section{ÖZ}

Bu çalıșma ile aromatik bir bitkinin üretiminde iyi bir organik madde ve potasyum kaynağı olduğu bilinen vinas ektresinin etkinliğinin belirlenmesi amaçlanmıştır. Bu kapsamda, bir gıda sanayi atığı olan vinas ekstresi kompostlandıktan sonra farklı dozlarda tek başına ve kimyasal gübre ile karıştırılarak [Sadece kimyasal gübreleme-kontrol (C), vinas kompostu $0.5 \mathrm{t} \mathrm{ha}^{-1}$ (VC-0.5), vinas kompostu $0.5 \mathrm{t} \mathrm{ha}^{-1}+$ kimyasal gübreleme $0.5 \mathrm{t} \mathrm{ha}^{-1}$ (VC-0.5+CF), vinas kompostu $1 \mathrm{t} \mathrm{ha}^{-1}$ (VC-1), vinas kompostu $1 \mathrm{t} \mathrm{ha}^{-1}+$ kimyasal gübreleme $\left.1 \mathrm{t} \mathrm{ha}^{-1}(\mathrm{VC}-1+\mathrm{CF})\right]$ toprağa uygulanmış ve böylece serada fesleğen bitkisi üretimi yapılmıştır. Bitkiler çiçeklenme dönemine geldikçe art arda $3 \mathrm{kez}$ hasat edilmiştir. Hasat edilen örneklerde morfolojik (bitkide dal sayısı, çiçek başak boyu, bitki boyu, taze ağırlık), agronomik (yeşil herba/drog verimi, kuru ağırlık) ve teknolojik (uçucu yağ oranı, uçucu yağ bileşimi, renk değeri) parametreler incelenmiştir. Elde edilen sonuçlara göre; bitkide en yüksek taze ağılık, yeşil herba verimi ve kuru ağırlık $\mathrm{VC}+\mathrm{CF}$ uygulamasıyla elde edilmiş iken bitkide en yüksek uçucu yağ oranı ise VC uygulamasında görülmüşsür. Burada dikkati çeken nokta ise kompostun düşük uygulama oranı olan $0.5 \mathrm{t} \mathrm{ha}^{-1}$ dozunda bu sonuçlara ulaşılmış olmasidır. Bu çalışma sonucunda elde edilen bulgular vinas kompostunun kimyasal gübrelemeyle birlikte fesleğen tarımında değerlendirilebileceğini ortaya koymaktadır. 


\section{Introduction}

Basil (Ocimum basilicum L.); belonging to the Lamiaceae family, one-year, native to India and Iran; is a medicinal and aromatic plant, common in Africa, South Asia and the Mediterranean coastline. Although naturally not present in the flora of Turkey, there are 35 species with localized types of basil (Baydar 2019). In addition to being used as a spice, it is also used as a medicinal plant due to its unique odor; that is, it contains important essential oil components (Ceylan 1995; Karik et al. 2014). The basil, which has a wide variety of morphological, chemotypic and ecotypic characteristics, is commercially grown in many countries. (Baydar 2019). It is also important to cultivate medicinal and aromatic plants in terms of preserving biological diversity. Thus, morphologic and phenotypic properties can be standardized (Yeşil et al. 2020).

Since medicinal and aromatic plants are very sensitive to environmental conditions like other plants, there are great differences in essential oil ratios and basic components in different ecologies. Researchers, in different regions of the world have done a lot of research on the determination of morphological, yield and quality characteristics of basil (Moghaddam 2010; Moawad et al. 2015; Singh et al. 2015; Yaldız et al. 2015; Cabar 2016; Ermişler 2017). In basil cultivation, as in other cultivated plants, plant sowing frequency and fertilizer application rates are among the most important factors affecting yield and plant height. It was reported that ecological factors and cultural practices determine the number of forms in a vegetation period, sowing or seedling planting period, fertilizer time and doses and planting frequency (Moghaddam 2010).

Although the rate of essential oil in the basil plant varies between $0.62 \%$ and $1.00 \%$, it has also been reported to increase up to 2\% (Baytop 1984; Akgül 1989; Arabac1 and Bayram 2004, Cabar 2016). In addition to the use of basil in meals as a spice, its essential oil is also used in the food industry and perfumery (Baytop 1984; Telci et al. 2006) and as a medicinal plant in Anatolia. Today, it was determined that the basil can also be used as a teeth whitening agent (Yeșil et al. 2020); a pesticide (Leyva et al. 2019; Chenni et al. 2020; Hoffmeister et al. 2020); a repellent (Ermişler 2017); a protector against bacterial and fungal spoilage (Atifa et al. 2020); a natural antioxidant (Hikmawenti et al. 2019); a food preservative (Szymandera-Buszka et al. 2020; Kerimoğlu et al. 2020) and as a feed additive in livestock (Ibrahim et al. 2019).

In sugar factories, after the plant's sugar part is extracted, the remaining pulp (vinasse) is a very valuable crystalline waste containing high levels of plant-derived protein, potassium, organic carbon, and some other nutrients. It was reported that this waste can be a very valuable input in animal nutrition and plant cultivation in the light of studies (Karaçal 2008). Especially in the cultivation of plants (banana, avocado, tomato, apple, corn, etc.) that exploit high potassium from the soil, it comes to mind that nutrient-rich organic fertilizing materials can be used as an alternative to or together with chemical fertilizers. Essentially, if the vinasse, which is a food industry waste, is stabilized/ composted, it may be considered as a soil conditioner or organic fertilizer in agricultural production. In this study, composted vinasse was applied to the soil alone and mixed with chemical fertilizers, and the basil cultivation was carried out under greenhouse conditions. In this way, it was tried to determine the efficiency of the compost in the cultural production of basil plant by examining the changes in the plant's morphological, agronomic and technological properties.

\section{Materials and Methods}

The study was carried out as a greenhouse experiment covering March, April, May, June and July in 2020. The experiment was carried out in Alanya Alaaddin Keykubat University, Gazipaşa M. Rahmi Büyükballı Vocational School campus $\left(36^{\circ} 15^{\prime} 41^{\prime \prime} \mathrm{K}\right.$ and $32^{\circ} 19^{\prime} 01^{\prime \prime} \mathrm{E}$, altitude $\left.16 \mathrm{~m}\right)$. Plants were grown in the plastic greenhouse with soil in this area. A previously installed drip irrigation system and equipment were used for irrigation in the greenhouse. Vinasse used as organic fertilizer material in the experiment was obtained from a fertilizer company in composted form. The analysis results of the vinasse used within the study's scope and the soil in the area where the experiment was established are shown in Table 1.

Table 1. Properties of the soil and the vinasse compost

\begin{tabular}{lrlc}
\hline Soil & Content & Vinasse compost & Content \\
\hline Texture & Clay & Organic carbon $(\%)$ & 17.46 \\
$\mathrm{pH}$ & 8.16 & Organic matter $(\%)$ & 30 \\
$\mathrm{EC}\left(\mu \mathrm{S} \mathrm{cm}^{-1}\right)$ & 327 & $\mathrm{pH}$ & 6.30 \\
Lime $(\%)$ & 17 & $\mathrm{C} / \mathrm{N}$ & $10 / 1$ \\
Organic matter $(\%)$ & 1.28 & Moist $(\%)$ & 10 \\
Total N $(\%)$ & 0.081 & Total N (\%) & 1.6 \\
Available P $\left(\mathrm{mg} \mathrm{kg}^{-1}\right)$ & 7.93 & Total P $(\%)$ & 1.5 \\
Exchangeable K $\left(\mathrm{mg} \mathrm{kg}^{-1}\right)$ & 118 & Total K $(\%)$ & 28 \\
\hline
\end{tabular}

Basil seeds (Vilmorin '504-1') were grown in a commercial seedling production facility. The seedling growing medium (peat, perlite and vermiculite; 3:1:1 ratio, respectively) used by the facility as a standard was used, and routine irrigation, nutrition and maintenance activities were carried out to make the seedlings ready within approximately 30 days. Before the experiment was established in the greenhouse, the soil was plowed with the help of a motorized hand hoe, it was cleared of weeds and the preliminary preparation was completed by leveling. Later, in accordance with the experiment plan, plots of 2 square meters $(0.5 \mathrm{~m}$ width, $4 \mathrm{~m}$ length and approximately 30 $\mathrm{cm}$ height) were created. Then, depending on the experimental subjects, the compost and chemical fertilizer (15.15.15-N.P.K) were weighed as reported by Baydar (2019) and these materials were homogeneously mixed into the plots by using a rake and hand anchor (Table 2). Seedlings that were previously obtained were planted at least 20 plants per plot $(20 \mathrm{~cm}$ above the row, $80 \mathrm{~cm}$ between rows). The experiment process was initiated by giving water through the drip irrigation system. After planting the seedlings, irrigation and hoeing were done as needed. As reported by Baydar (2019), the harvests were carried out when

Table 2. Treatments in the experiment

\begin{tabular}{ll}
\hline Treatment & Content \\
\hline C & Control (only chemical fertilization $\left.0.5 \mathrm{t} \mathrm{ha}^{-1}\right)$ \\
VC-0.5 & Vinasse compost $\left(0.5 \mathrm{tha}^{-1}\right)$ \\
VC-0.5+CF & Vinasse compost $\left(0.5 \mathrm{t} \mathrm{ha}^{-1}\right)+$ Chemical fertilizer \\
& $\left(0.5 \mathrm{tha}^{-1}\right)$ \\
VC-1 & Vinasse compost $\left(1 \mathrm{t} \mathrm{ha}^{-1}\right)$ \\
VC-1+CF & Vinasse compost $\left(1 \mathrm{tha}^{-1}\right)+$ Chemical fertilizer \\
& $\left(0.5 \mathrm{tha}^{-1}\right)$ \\
\hline
\end{tabular}


the plants were in full bloom when the amount of essential oil was the highest. In this way, a total of three harvests were made on 26 April 2020, 04 June 2020 and 02 July 2020.

The following analyzes were carried out on the compost used as fertilizing material in the experiment. Organic matter content was determined according to the oven-dry method (Kacar 1995). The material's $\mathrm{pH}$ and EC values were determined by a pH-EC meter (Jackson 1967). Total nitrogen (N) determination was made according to the modified Kjeldahl method (Kacar and Inal 2008). Total phosphorus (P) and total potassium $(\mathrm{K})$ analyzes were made according to the wet decomposition method (Kacar 1995). In order to determine the initial soil properties of the experiment area, a soil sample was taken from a depth of 0-30 cm. For chemical analysis, the soil sample was sieved through a $2 \mathrm{~mm}$ sieve and made ready for analysis. In terms of parameters examined in soil samples, chemical analyzes were made as follows: Texture (Bouyoucos 1951), lime (Çağlar 1949), pH and EC (Jackson 1967), organic matter (Black 1965), total N (modified Kjeldahl-Kacar 1995), available P (Olsen and Sommers 1982), exchangeable K (Kacar 1995).

As part of the experiment, the morphological, agronomic and technological properties detailed below were determined in the plant samples obtained at harvest. For each repetition, operations (measurement, weighing, calculation, etc.) were made on five plants obtained from the plots and the results were given as the average of these. Morphological properties: Number of branches in the plant (pieces), flower spike length $(\mathrm{cm})$, plant height $(\mathrm{cm})$ and fresh weight $(\mathrm{g})$. Agronomic properties: Green herb/drug yield $\left(\mathrm{kg} \mathrm{da}^{-1}\right)$, dry weight $\left(\mathrm{g}\right.$ plant $\left.\mathrm{t}^{-1}\right)$. Technological properties: Essential oil ratio (\%), essential oil composition and color value ( $\left.L^{*}, a^{*}, b^{*}\right)$.

By pre-cleaning the basil materials brought to the laboratory, foreign substances on the plant were removed. Drying processes were carried out in 48 hours in an oven dryer (Venticell-404 Standard, MMM group, Germany) with air circulation $\left(7.272 \mathrm{~m}^{3}\right.$ hour $\left.{ }^{-1}\right)$ set at $40^{\circ} \mathrm{C}$. To obtain essential oil, $25 \mathrm{~g}$ of dry plant material was distilled for 120 minutes by using a clavenger apparatus and the obtained essential oil ratio was given as \%. Essential oil composition analysis was carried out according to Özek et al. (2010) method and using capillary column [(HP Innowax Capillary; $60.0 \mathrm{mx} 0.25 \mathrm{~mm} \times 0.25 \mu \mathrm{m}$ ) with GC/-MS-FID (Gas chromatography (Agilent 7890A) mass detector (Agilent 5975C)]. Samples were diluted 1:50 with hexane for analysis. Helium gas was used as carrier gas at a flow rate of $0.8 \mathrm{~mL} \mathrm{~min}{ }^{-1}$ in the analysis, and samples were injected into the device as $1 \mu \mathrm{L}$ at a split ratio of $40: 1$. Injector temperature was set to be $250^{\circ} \mathrm{C}$, column temperature program $60^{\circ} \mathrm{C}$ (10 minutes), $4^{\circ} \mathrm{C}$ minute ${ }^{-1}$ and $220^{\circ} \mathrm{C}(10$ minutes) from $60^{\circ} \mathrm{C}$ to $220^{\circ} \mathrm{C}$. The total analysis time in line with this temperature program is 60 minutes. Scanning range $(\mathrm{m} / \mathrm{z})$ 35-450 atomic mass units and electron bombardment ionization $70 \mathrm{eV}$ were used for the mass detector. In the identification of essential oil components, the data of WILEY and OIL ADAMS libraries were used. Component percentages of the results were made using the FID detector, and the diagnosis of the components was made using the MS detector.

Fresh and dry leaf colors of the basil plants were measured with a portable tristimulus reflectance colorimeter Minolta CR-400 Chroma Meter (Konica Minolta Sensing, Inc., Osaka, Japan) and the parameters were expressed in CIE $\mathrm{L}^{*}, \mathrm{a}^{*}, \mathrm{~b}^{*}$ system, where $\mathrm{L}^{*}$ is lightness (brightness-darkness) ranged from 0 to 100 units, $a^{*}$ is light intensity in red (+) or green (-) spectrum, b* is intensity in yellow (+) or blue (-) spectrum (Giovanelli and Paradiso 2002).

The numerical data obtained from the greenhouse experiment were statistically evaluated using the SPSS 17.0 package program. In this context, the significance of the results obtained was determined by repeated measurement ANOVA (rANOVA) analysis (at the level of 5\%), the results found important were graded by letters with Duncan multiple comparison test (SPSS 2008).

\section{Results and Discussion}

\subsection{Morphological properties}

The effects of the applications tried in the research on the morphological properties of the basil plant are given in Table 3. As seen in the table, although there is no significant difference between the applications in terms of the number of branches, flower spike height and plant height, there is a significant difference $(P<0.05)$ between control $(52.26 \mathrm{~g})$ and other applications in terms of fresh weight. The highest fresh weight was detected in the application of VC-0.5+CF (64.43 g). ElSayed et al. (2015), in their study on three different basil species, stated that $100 \mathrm{~g}$ chicken manure and $125 \mathrm{ppm}$ humic acid application increased the plant wet weight. However, considering the harvest periods, the number of branches increased in the third harvest period (10.01 pieces); the longest flower spike height $(17.52 \mathrm{~cm})$ in the second harvest period; the longest plant height is $44.58 \mathrm{~cm}$ in the second harvest period; fresh weight also reached the highest values (63.45 $\mathrm{g}$ and 65.66 $\mathrm{g})$ in the first harvest period.

Yaldız et al. (2015) examined the yield and quality criteria of green and purple colored basil varieties according to different harvest periods. They reported that the plant height of green-colored varieties grown in the open field was 55.53-98.70 $\mathrm{cm}$. Singh et al. (2015) determined in their study in India that the average plant height in basil was $87.15-119.98 \mathrm{~cm}$, and the number of branches was 9.00-11.24 per plant. Ceylan (1997) reported that a basil plant that has completed its development is usually between 30 and $60 \mathrm{~cm}$. Aslan (2014) found that the basil plant's flower spike length ranged from 14.21 to $30.14 \mathrm{~cm}$; reported that the plant height values ranged from 37.70 to 95.00 $\mathrm{cm}$. The values obtained in terms of plant height have similar values with the $0-40 \mathrm{~cm}$ specified by Baytop (1984). In parallel with the results we obtained, Özgen (2014) reported that the second form plant heights reached the highest value in his experiment conducted on 14 different basil lines. Singh et al. (2015) determined the average number of branches in basil as 9.00-11.24 pieces/plant in their study in India. Randhawa and Bill (1995) investigated the effects of different planting dates on the herb yield and essential oil ratio of basil; they stated that increasing temperature and relative humidity encourage the plant to branch.

\subsection{Agronomic properties}

When the effects of the applications tried in the research on the agronomic properties of the basil plant are examined; VC-0.5+CF application with maximum $644 \mathrm{~kg} \mathrm{da}^{-1}$ was found important in terms of green herb/drug yield (Table 4). In terms of dry weight, the application and harvest periods were statistically significant, as well as the interaction of the application and harvest period. Among the applications, the maximum dry weight was obtained from the application of 
Table 3. The effects of the applications on the morphological properties of the plant

\begin{tabular}{|c|c|c|c|c|c|c|c|c|c|c|c|c|}
\hline Treatment & \multicolumn{3}{|c|}{$\begin{array}{c}\text { Number of branches } \\
\text { (pieces) }\end{array}$} & \multicolumn{3}{|c|}{ Flower spike height (cm) } & \multicolumn{3}{|c|}{ Plant height $(\mathbf{c m})$} & \multicolumn{3}{|c|}{ Fresh weight (g) } \\
\hline $\mathrm{C}$ & \multicolumn{3}{|c|}{8.80} & \multicolumn{3}{|c|}{14.42} & \multicolumn{3}{|c|}{38.87} & \multicolumn{3}{|c|}{$52.26 \mathrm{c}^{1}$} \\
\hline VC-0.5 & \multicolumn{3}{|c|}{8.40} & \multicolumn{3}{|c|}{15.40} & \multicolumn{3}{|c|}{38.61} & \multicolumn{3}{|c|}{$57.52 \mathrm{~b}$} \\
\hline VC-0.5+CF & \multicolumn{3}{|c|}{8.67} & \multicolumn{3}{|c|}{15.35} & \multicolumn{3}{|c|}{39.52} & \multicolumn{3}{|c|}{$64.43 \mathrm{a}$} \\
\hline VC-1 & \multicolumn{3}{|c|}{8.96} & \multicolumn{3}{|c|}{13.21} & \multicolumn{3}{|c|}{36.29} & \multicolumn{3}{|c|}{$61.25 \mathrm{ab}$} \\
\hline $\mathrm{VC}-1+\mathrm{CF}$ & \multicolumn{3}{|c|}{8.56} & \multicolumn{3}{|c|}{14.25} & \multicolumn{3}{|c|}{37.26} & \multicolumn{3}{|c|}{$56.30 \mathrm{~b}$} \\
\hline \multicolumn{13}{|c|}{ Sampling time (harvest) } \\
\hline \multirow{2}{*}{ Mean } & I & II & III & $\mathrm{I}$ & II & III & I & II & III & I & II & III \\
\hline & $7.98 \mathrm{~b}$ & $8.02 \mathrm{~b}$ & $10.01 \mathrm{a}$ & $14.45 b$ & $17.52 \mathrm{a}$ & $11.59 \mathrm{c}$ & $30.72 \mathrm{c}$ & $44.58 \mathrm{a}$ & $39.01 \mathrm{~b}$ & $63.45 \mathrm{a}$ & $65.66 \mathrm{a}$ & $45.93 b$ \\
\hline \multicolumn{13}{|c|}{ rANOVA (LSD 5\%) } \\
\hline $\begin{array}{c}\text { Harvest } \\
(\mathbf{H})\end{array}$ & \multicolumn{3}{|c|}{$17.230^{* * * 2}$} & \multicolumn{3}{|c|}{$15.850^{* * *}$} & \multicolumn{3}{|c|}{45.857 *** } & \multicolumn{3}{|c|}{$7.560^{* * 3}$} \\
\hline $\begin{array}{l}\text { Treatment } \\
\text { (U) }\end{array}$ & \multicolumn{3}{|c|}{ NS } & \multicolumn{3}{|c|}{ NS } & \multicolumn{3}{|c|}{ NS } & \multicolumn{3}{|c|}{$1.071^{* 4}$} \\
\hline H x U & \multicolumn{3}{|c|}{ NS } & & NS & & & NS & & & $\mathrm{NS}^{5}$ & \\
\hline
\end{tabular}

Table 4. The effects of the applications on the agronomic properties of the plant

\begin{tabular}{|c|c|c|c|c|c|}
\hline Treatment & \multicolumn{2}{|c|}{ Green herb/drug yield $\left(\mathrm{kg} \mathrm{da}^{-1}\right)$} & \multicolumn{3}{|c|}{ Dry weight (g) } \\
\hline $\mathbf{C}$ & \multicolumn{2}{|c|}{$523 d^{1}$} & \multicolumn{3}{|c|}{$39.12 \mathrm{~d}$} \\
\hline VC-0.5 & \multicolumn{2}{|c|}{$575 \mathrm{c}$} & \multicolumn{3}{|c|}{$42.00 \mathrm{bc}$} \\
\hline $\mathrm{VC}-0.5+\mathrm{CF}$ & \multicolumn{2}{|c|}{$644 a$} & \multicolumn{3}{|c|}{$49.37 \mathrm{a}$} \\
\hline VC-1 & \multicolumn{2}{|c|}{$613 b$} & \multicolumn{3}{|c|}{$44.56 \mathrm{~b}$} \\
\hline $\mathrm{VC}-1+\mathrm{CF}$ & \multicolumn{2}{|c|}{$563 \mathrm{~cd}$} & \multicolumn{3}{|c|}{$40.38 \mathrm{c}$} \\
\hline \multicolumn{6}{|c|}{ Sampling time (harvest) } \\
\hline \multirow{2}{*}{ Mean } & I & III & I & II & III \\
\hline & $635 b$ & $459 \mathrm{c}$ & $40.16 \mathrm{~b}$ & $53.65 \mathrm{a}$ & $35.44 \mathrm{~b}$ \\
\hline \multicolumn{6}{|c|}{ rANOVA (LSD 5\%) } \\
\hline Harvest $(\mathbf{H})$ & & & & $11.598 * * * 2$ & \\
\hline Treatment (U) & & & & $2.178^{*}$ & \\
\hline $\mathbf{H} \times \mathbf{U}$ & & & & $2.118^{*}$ & \\
\hline
\end{tabular}

${ }^{1}$ Means in the same column followed by the same letter are not significantly different at the $5 \%$ level according to Duncan's multiple range test, ${ }^{2} * * * \quad P<0.001$, $3 * * P<0.01,{ }^{4} * P<0.05,{ }^{5} \mathrm{NS}$ : Not significant.

VC- $0.5+\mathrm{CF}$ with $49.37 \mathrm{~g}$ and the dry weight obtained in the second harvest period $(53.65 \mathrm{~g}-P<0.001)$ was statistically found to be the highest (Table 4). Yaldiz et al. (2015) found that fresh herb yield 1190.1-2988.0 $\mathrm{kg} \mathrm{da}^{-1}$, dry herb yield 195.1-427.5 $\mathrm{kg} \mathrm{da}^{-1}$. Singh et al. (2015) found green herb yield $1651.23-2317.00 \mathrm{~kg} \mathrm{da}^{-1}$, dry herb yield $770.27-1190.38 \mathrm{~kg} \mathrm{da}^{-1}$. Aslan (2014) reported that the basil plant's green herb yield was $612.50-4640.63 \mathrm{~kg} \mathrm{da}^{-1}$. Chang et al. (2005) found green herb yield between $37.6-47.9 \mathrm{~g} \mathrm{plant}^{-1}$ in his study and explained that this difference was formed by the effect of temperature. With the effect of increasing temperatures, the lowest green herb yield was obtained at the third harvest time as a result of the plant's flowering by passing to the generative period before completing the vegetative growth.

\subsection{Technological properties}

The effects of different applications on the essential oil ratio and color values, which are the technological properties of the plant, are summarized in Table 5. Highest essential oil ratio was obtained as $0.86 \%$ in the application of VC-0.5. When we look at the harvest periods, this value was found as $0.48 \%$ in the first harvest, $0.74 \%$ in the second harvest and $1.15 \%$ in the third harvest. The rates of essential oil increased as the harvest periods increased. In this respect, statistically $(P<0.001)$, the highest essential oil ratio was obtained in the third harvest period. Singh et al. (2015) stated the essential oil yield in basil as 3.37-3.67 $1 \mathrm{da}^{-1}$ in their study in India. Hornok and Lenches (1992) reported that fertilization increases the rate of essential oil. Different researchers reported the essential oil rates in basil as follows; Telci et al. (2006), in their study, between 0.59$0.95 \%$ and Arabac1 and Bayram (2004) stated that it was between $0.62-1.00 \%$. The results were obtained to support these studies.

When the color values of the dried basil samples were examined, the $\mathrm{L}^{*}$ and $\mathrm{a}^{*}$ values did not show a significant difference depending on the application. At the same time, the first and second harvest times were statistically separated from the third harvest time (Table 5). When the $b^{*}$ values that give yellow (-60) and blue $(+60)$ color are examined, it is seen that the applications and harvest times have created statistically significant differences. VC-0.5 application is yellow, VC-1 application is close to blue, $\mathrm{C}, \mathrm{VC}-0.5+\mathrm{CF}$ and $\mathrm{VC}-1+\mathrm{CF}$ applications are in the same group between these two applications. On the other hand, dry plant color values measured in the study; the $\mathrm{L}^{*}$ was found to be $53.32-48.68$, the a* was $-8.44--9.65$ and the $b^{*}$ was $23.97-20.78$ (Table 5).

In this study, a total of 19 components in essential oils were determined (Table 6). Main components in essential oils; linalool $69.4 \%, \alpha$-bergamoten $10.29 \%$ and 1,8 -cineole $9.95 \%$. Moghaddam (2010) stated that not only the rate of essential oil but also the components of the essential oil are important in essential oil-containing plants; linalool and $\alpha$-bergamoten-like 
Table 5. The effects of the applications on the technological properties of the plant

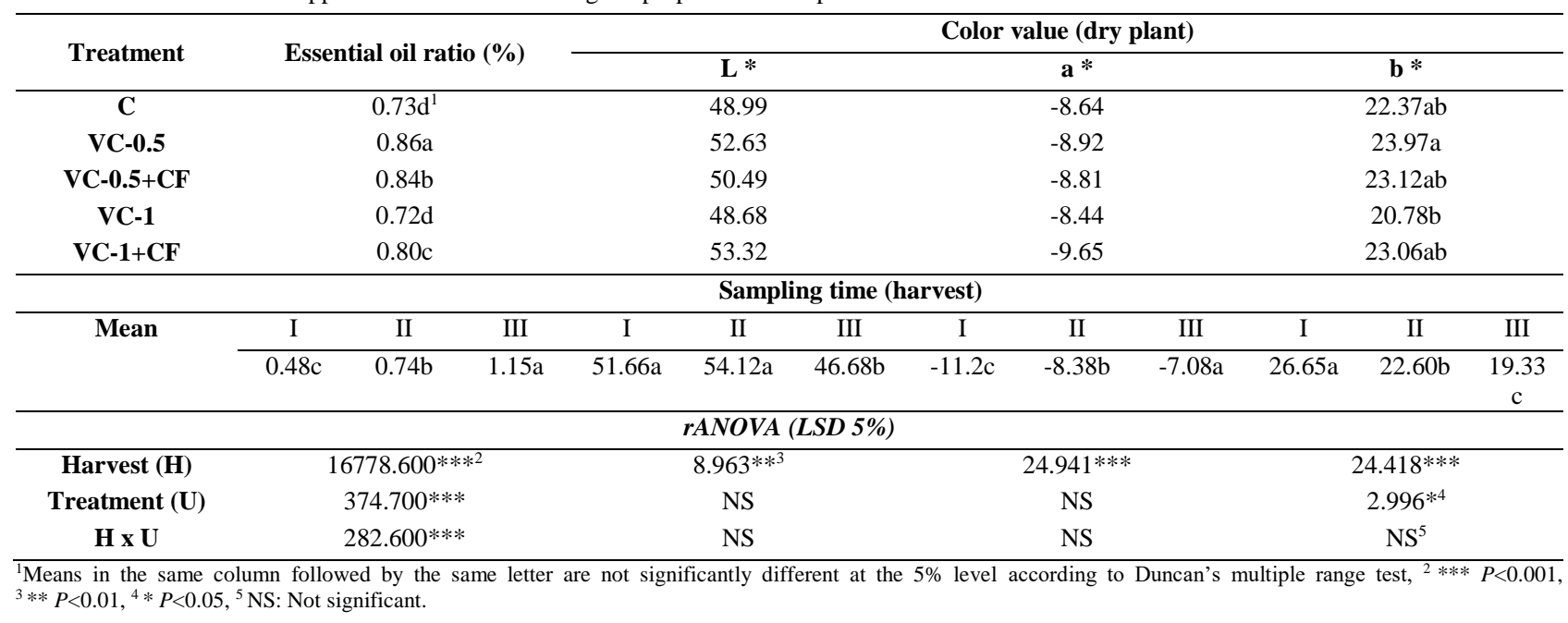

Table 6. The effects of the applications on the essential oil composition of the plant

\begin{tabular}{|c|c|c|c|c|c|c|c|c|c|c|c|c|c|c|c|}
\hline \multirow{4}{*}{ Composition } & \multicolumn{15}{|c|}{ Treatment } \\
\hline & \multicolumn{3}{|c|}{$\mathrm{C}$} & \multirow{2}{*}{\multicolumn{2}{|c|}{ VC-0.5 }} & \multicolumn{4}{|c|}{$\mathrm{VC}-0.5+\mathrm{CF}$} & \multicolumn{3}{|c|}{ VC-1 } & \multicolumn{3}{|c|}{$\mathrm{VC}-1+\mathrm{CF}$} \\
\hline & \multicolumn{13}{|c|}{ Sampling time (harvest) } & & \\
\hline & I & II & III & I & II & III & I & II & III & I & II & III & I & II & III \\
\hline (1) 1.8-cineole & 8.37 & 6.82 & 7.91 & 6.34 & 6.13 & 7.63 & 7.24 & 8.17 & 7.10 & 9.95 & 5.06 & 9.09 & 7.16 & 6.78 & 6.67 \\
\hline (2) linalool & 67.89 & 61.88 & 62.68 & 66.46 & 64.07 & 65.72 & 69.40 & 52.34 & 63.01 & 64.21 & 55.56 & 59.56 & 64.59 & 60.27 & 67.84 \\
\hline $\begin{array}{l}\text { (3) bornyl } \\
\text { acetate }\end{array}$ & 1.32 & - & - & 1.33 & 0.53 & - & 1.25 & - & - & 1.24 & - & - & 1.62 & - & - \\
\hline $\begin{array}{l}\text { (4) alpha- } \\
\text { bergamotene }\end{array}$ & 7.11 & 7.18 & 5.44 & 9.34 & 6.51 & 4.10 & 7.85 & 7.96 & 6.08 & 9.81 & 0.88 & 4.66 & 10.29 & 7.08 & 4.18 \\
\hline (5) beta-elemene & 1.13 & 1.16 & - & 1.39 & 1.26 & - & 1.28 & 1.22 & 0.77 & 1.31 & 1.73 & 0.62 & 1.64 & 1.23 & - \\
\hline $\begin{array}{l}\text { (6) beta- } \\
\text { farnesene }\end{array}$ & 0.63 & - & - & 1.22 & - & - & 0.56 & 0.48 & - & 1.21 & 0.52 & - & 1.28 & 0.42 & - \\
\hline $\begin{array}{l}\text { (7) alpha- } \\
\text { terpineol }\end{array}$ & 0.49 & 0.73 & 0.46 & 0.39 & 0.77 & 0.37 & 0.47 & 0.88 & 0.51 & 0.46 & 0.76 & 0.88 & 0.46 & 0.69 & 0.33 \\
\hline (8) germacrene & 1.52 & 1.45 & 0.77 & 1.93 & 1.65 & 0.71 & 1.76 & 1.54 & 0.97 & 1.83 & 2.25 & 0.80 & 2.43 & 1.74 & 0.84 \\
\hline $\begin{array}{l}\text { (9) citronellyl } \\
\text { formate }\end{array}$ & 3.03 & - & - & - & - & - & 0.83 & - & - & & - & - & - & - & - \\
\hline $\begin{array}{l}\text { (10) gamma- } \\
\text { cadinene } \\
\text { (11) 10-epi- }\end{array}$ & 0.92 & 1.06 & 0.69 & 1.32 & 0.90 & 0.61 & 1.16 & 1.03 & 0.86 & 1.37 & 1.29 & 0.67 & 1.41 & 0.97 & 0.65 \\
\hline $\begin{array}{l}\text { gamma- } \\
\text { eudesmol }\end{array}$ & 0.59 & - & - & - & - & - & - & - & - & - & - & - & 0.48 & - & - \\
\hline (12) eugenol & 3.94 & 15.00 & 18.56 & 4.64 & 13.91 & 17.46 & 4.82 & 20.75 & 17.55 & 4.54 & 18.73 & 18.30 & 3.73 & 15.67 & 16.27 \\
\hline (13) tau-cadinol & 3.07 & 2.80 & 1.91 & 3.53 & 2.46 & 1.92 & 3.39 & 2.81 & 2.40 & 3.45 & 3.63 & 2.02 & 3.60 & 2.90 & 2.00 \\
\hline (14) beta-pinene & - & 0.61 & 0.71 & 0.79 & 0.54 & 0.68 & - & 0.88 & - & 0.64 & - & 0.90 & 0.67 & 0.71 & 0.57 \\
\hline $\begin{array}{l}\text { (15) beta- } \\
\text { ocimene }\end{array}$ & - & 0.75 & 0.86 & 0.70 & 0.71 & 0.80 & - & 1.28 & 0.75 & - & 0.89 & 1.00 & 0.65 & 0.95 & 0.66 \\
\hline (16) borneol & - & - & - & - & - & - & - & 0.67 & - & - & 0.70 & - & - & 0.60 & - \\
\hline $\begin{array}{l}\text { (17) beta- } \\
\text { myrcene }\end{array}$ & - & - & - & 0.61 & - & - & - & - & - & - & - & 0.56 & - & - & - \\
\hline (18) borneol & - & 0.57 & - & - & 0.58 & - & - & - & - & - & - & 0.52 & - & - & - \\
\hline $\begin{array}{l}\text { (19) alpha- } \\
\text { pinene }\end{array}$ & - & - & - & - & - & - & - & - & - & - & - & 0.41 & - & - & - \\
\hline
\end{tabular}

components in the basil plant report that they are widely used in food and pharmacy. The values found by the researchers in this regard are as follows; Karık et al. (2014) reported a total of 23 components, linalool (74.03\%) and 1,8-cineole (44.94\%). Mota et al. (2020) reported that linalool, one of the essential oil components of basil, was $52.8 \%$ under water stress conditions in their study on the basil plant. Biró-Janka et al. (2019) reported a total of 25 essential oil components in basil and $70.15 \%$ linalool as the main component in their study in Romania. Additionally, Yaldiz et al. (2015) reported that the main components of essential oil in green and purple basil varieties at different harvest periods were linalool $6.9-42.7 \%$, methyl cinnamate $10.4-19.1 \%$, eugenol $8.9-13.0 \%$, 1.8-cineol $0.2-1.9 \%, \beta$-kubenen $1.0-1.7 \%$, trans-caryophyllene $1.2-2.7 \%$, farnesene $10.2-21.1 \%$, germakren-D $1.3 \%$, 1.6-kadenine $7.0-9.2 \%$. It appears that the main component of basil essential oil is usually linalool, although it varies according to studies reported from different ecologies.

\section{Conclusion}

Organic fertilizers are important in medicinal and aromatic plant cultivation, where chemical fertilization is not generally recommended. It is known that it is not possible to grow 
medicinal and aromatic plants rich in secondary metabolites only with chemical fertilization. However, organic fertilization may not be sufficient for an industry-oriented standard plant cultivation. For these reasons, minimizing the use of chemical fertilizers by using organic fertilizing materials and/or soil conditioners and decreasing fertilizer costs will provide high benefits in terms of both medicinal-aromatic plant cultivation and nature protection. In this study, in addition to chemical fertilization, two different application rates of the compost, which is a sugar factory waste, were applied and it was aimed to spread organic fertilization in an aromatic plant cultivation. The findings obtained from this study reveal that the compost can be used in basil cultivation together with chemical fertilization. One of the most important results of this study is that the VC- 0.5 increases the essential oil ratio by $20 \%$ compared to the control group. On the other hand, in terms of increasing the reliability of the results, it is clear that new studies with different factors such as climate, soil type, water regime, production model are needed. In this way, the effectiveness of fertilizing materials of organic origin such as the vinasse in medicinal and aromatic plant growing can be demonstrated.

\section{Acknowledgments}

We thank the Western Mediterranean Agricultural Research Institute (BATEM), Deryagri Agriculture L.L.C. and Kircami Seedling L.L.C. for their support in this study.

\section{References}

Akgül A (1989) Volatile oil composition of sweet basil (Ocimum basilicum L.). Cultivating in Turkey. Food Science Department, Faculty of Agriculture, Atatürk University, Erzurum, s. 87-88.

Arabaci O, Bayram E (2004) The effect of nitrogen fertilization and different plant densities on some agronomic and technologic characteristic of Ocimum basilicum L. (basil). Journal of Agronomy 3(4): 255-262.

Aslan DF (2014) Farklı Reyhan (Ocimum basilicum L.) Genotiplerinde Ontogenetik ve Morfogenetik Varyabilitenin Belirlenmesi. Adnan Menderes Üniversitesi, Fen Bilimleri Enstitüsü, Tarla Bitkileri Anabilim Dalı, Yüksek Lisans Tezi, Aydın.

Atifa M, ,Soundarrajan I, Sandhanasamy D, Mohamad SA, Ki Choon C, Ponnuswamy V, Akram AA, Naif F (2020) Essential oils of two medicinal plants and protective properties of jack fruits against the spoilage bacteria and fungi. Industrial Crops \& Products 147: 112239.

Baydar H (2019) Tibbi ve Aromatik Bitkiler Bilimi ve Teknolojisi. Nobel Akademik Yayıncılık. ISBN: 978-605-7846-38-9.

Baytop T (1984) Treatment with Plants in Turkey, Istanbul University Pub 1, No. 3255, İstanbul, Turkey.

Biró-Janka B, Nyárádi I, Vârban DI, Molnár K, Duda MM (2019) Comparing The Plants Biomassand The Volatile Oil Content of Sweet Basıl (Ocimumbasilicum L.). Cultivars Grown in TÂRGU MUREȘ. Hop and Medicinal Plants, No. 1-2, ISSN 2360-0179 ISSN 2360-0187 electronic.

Black CA (1965) Methods of Soil Analysis. Part:2. Chemical and Microbiological Properties, editor A L Page, RH Miller, D R Keeney, Madison, Wisconsin, SSSA Inc.

Bouyoucos GJ (1951) A Recalibration of hydrometer method for making mechanical analysis of soils. Agronomy Journal 43: 43438.

Cabar BS (2016) Farklı fesleğen (Ocimum basilicum L. ) hatlarının trakya koşullarında verim ve kalite ile ilgili bazı özelliklerinin belirlenmesi. Yüksek Lisans Tezi, Namık Kemal Üniversitesi Fen Bilimleri Enstitüsü, Tekirdağ.
Çağlar KO (1949) Toprak Bilgisi. Ankara Üniversitesi Ziraat Fakültesi Yayınları, No: 10.

Ceylan A (1995) T1bbi Bitkiler I. 3. Bask1, Ege Üniversitesi Ziraat Fakültesi Yayınları, No: 312.

Ceylan A (1997) Tıbbi Bitkiler (Uçucu Yağ Bitkileri) Cilt II. Ege Üniversitesi Ziraat Fakültesi Yayınları, No: 481.

Chang X, Alderson PG, Wright CJ (2005) Effect of temperature integration on the growthand volatile oilcontent of basil (Ocimum basilicum L.). Journal of Horticultural Science and Biotechnology 80(5): 593-600.

Chenni M, Douniazad EA, Samir N, Njara R, Xavier F, Farid C (2020) Solvent free micro wave extraction followed by encapsulation of Ocimum Basilicum L. essential oil for insecticide purpose. Journal of Stored Products Research 86: 1-8.

El-Sayed AA, El-Hanafy SH, El-Ziat RA (2015) Effect of chicken manure and humic acid on herb and essential oil production of Ocimum sp. American-Eurasian. Journal of Agricultural and Environmental Sciences 15: 367-379.

Ermişler A (2017) Altın otu (Helichry sumarenarium) ve fesleğen (Ocimum basilicum L.) bitkilerinin sinek kovucu (repellent) özelliklerinin karşılaştırılması. Yüksek Lisans Tezi, Selçuk Üniversitesi Fen Bilimleri Enstitüsü, Konya.

Giovanelli G, Paradiso, A (2002) Stability of dried and intermediate moisture tomato pulp during storage. Journal Agriculture Food Chemical 50(25): 7277-7281.

Hikmawenti NPE, Hariyanti N, Sahera N (2019) Chemical components of Ocimum basilicum L. and Ocimum tenuiflorum L. Stem essential oils and evaluation of their antioxidant activities using DPPH method. Pharmaceutical Science and Research 6(3): 149-154.

Hoffmeister M, Maier W, Thines M, Becker, Y (2020) Tracking host infection and reproduction of peronospora salvia officinalis using an improved method for confocallasers canning microscopy. Plant Pathology 69: 922-931.

Hornok L, Lenches O (1992) Sweet Basil. Cultivation and Processing of Medicinal Plants (Editor Hornok L), University of Horticultural Sciences, Budapest, pp. 220-224.

Ibrahim MAS, Magda M, Abdel Fattah GME, Mallahand HE (2019) Effect of some herbs as feed additives on performance digestibility, carcass characteristics and blood parameters of broilers. The Egyptian Society of Nutrition and Feeds, Egyptian Journal Nutrition and Feeds 22(1): 191-199.

Jackson ML (1967) Soil Chemical Analysis. Prentice Hall of India Private Limited, New Delhi.

Kacar B (1995) Bitki ve Toprağın Kimyasal Analizleri. Ankara Üniversitesi Ziraat Fakültesi Eğitim, Araştırma ve Geliştirme Vakfi Yayınları, Ankara, No: 3.

Kacar B, İnal A (2008) Bitki Analizleri. Nobel Yayınları, Ankara, No: 1241.

Karaçal İ (2008) Toprak Verimliliği. Nobel Yayın, 1. Basım, Ankara, No: 1335, s. 222.

Karık U, Çiçek F, Oğur E, Çınar O, Birol, D (2014) Menemen ekolojik koşullarında bazı ticari ve yerel fesleğen (Ocimum basilicum L.) çeşitlerinin morfolojik, verim ve kalite özelliklerinin belirlenmesi. Anadolu 24(2): 10-20.

Kerimoğlu BO, Kavuşan HS, Serdaroğlu M (2020) The impacts of laurel (Laurus nobilis) and basil (Ocimum basilicum) essential oils on oxidative stability and freshness of sous-vide sea bass fillets. Turk Journal Veterinary Animal Science 44: 101-109.

Leyva M, Oriela P, María del CM, Juan AP, Ramón S, Gisel M, Domingo M (2019) Ovicidal activity and repellent of essential oils on the oviposition of aedes a Egypti and Aedes albopictus (Diptera: culicidae). Integrative Journal of Veterinary Biosciences 3(1): 1-6.

Moawad SA, El-Ghorab AH, Hassan M, Nour-Eldin H, El-Gharabli MM (2015) Chemical and microbiological characterization of 
Egyptian cultivars for some spices and-herbs commonly exported abroad. Food and Nutrition Sciences 6: 643-659.

Moghaddam DAM (2010) Fesleğen (Ocimum basilicum L.)'de farklı bitki sıklığı ve azot dozlarının verim ve verim öğeleri, uçucu yağ oranı ve bileşenler üzerine etkileri. Doktora Tezi, Ankara Üniversitesi Fen Bilimleri Enstitüsü, Ankara.

Mota I, Sanchez J, Pedro LG, Sousa MJ (2020) Composition variation of the essential oil from Ocimum basilicum L., cv. Genovese Gigante in response glomusin traradices and mild water stres at different stages of growth. Biochemical Systematics and Ecology 90: 104021.

Olsen SR, Sommers LE (1982) Phosphorus In Methods of Soils Analysis, Part:2. Chemical and Microbiological Properties, editor A L Page, RH Miller, D R Keeney, Madison, Wisconsin, SSSA Inc.

Özek G, Demirci F, Özek T, Tabanca N, Wedge DE, Khan SI, Başer KHC, Duran A, Hamzaoglu E (2010) Gaschromatographic massspectrometric analysis of volatile sobtained by four different techniques from Salviarosi folia Sm and evaluation for biological activity. Journal of Chromatography 1217: 741-748.

Özgen Y (2014) Farklı reyhan (Ocimum basilicum L.) hatlarının bazı kimyasal ve morfolojik özelliklerinin belirlenmesi üzerine çalışmalar. Yüksek Lisans Tezi, Ankara Üniversitesi Fen Bilimleri Enstitüsü, Ankara.

Randhawa GS, Bill BS (1995) Transpanting dates, harvesting stage and yields of french Basil (Ocimum basilicum L.). Journal of Herbs, Species and Medicinal Plants 3(1): 45-55.
Singh R, Shushni MA, Belkheir A (2015) Antibacterial and antioxidant activities of Mentha piperita L.. Arabian Journal of Chemistry 8(3): 322-328.

SPSS (2008) Statistical Package for Social Sciences Program. Version 17 for Windows, SPSS Inc., Chicago.

Szymandera-Buszka K, Katarzyna W, Anna J (2020) Sensory analysis in assessing the possibility of using ethanol extracts of spices to develop new meat products. Foods 9: 209, doi: 10.3390 / foods 9020209.

Telci I, Bayram E, Yılmaz G, Avcı B (2006) Variability in essential oil composition of Turkish basils (Ocimum basilicum L.). Biochemical Systematics and Ecology 34(6): 489-497.

Yaldız G, Gül F, Kulak M (2015) Herb yield and chemical composition of basil (Ocimum basilicum L.) esential oil in relation to the different harvest period and cultivation conditions. African Journal of Traditional Complementary and Alternative Medicines 12: 7176.

Yeşil M, Öztürk İ, Duymus ZY, Özcan MM (2020) Evaluating the effect of some medicinal plants (Mentha piperita, Ocimum basilicum, Rosmarinus officinalis, Salvia officinalis) on whitening of the permanent teeth. Turkish Journal of Agriculture-Food Science and Technology 8(1): 1-6. 